\title{
Evaluation of Viable Alternative Crops for FCV Tobacco in Southern Black Soils of Prakasam District of Andhara Pradesh, India
}

\author{
G. Ramesh $^{1 *}$, Ch. Varaprasada Rao ${ }^{1}$ and G. M. V. Prasada Rao ${ }^{3}$ \\ ${ }^{1}$ DAATTC, Darsi, India \\ ${ }^{2}$ Krishi Vigyan Kendra, Drasi, AP, India \\ *Corresponding author
}

A B S T R A C T

\begin{tabular}{l} 
K e y w o r d s \\
FCV tobacco, \\
$\begin{array}{l}\text { Alternative crops, } \\
\text { Land equivalent } \\
\text { ratio }\end{array}$ \\
\hline Article Info \\
\hline $\begin{array}{l}\text { Accepted: } \\
\text { 28 July 2020 } \\
\text { Available Online: } \\
\text { 10 August } 2020\end{array}$ \\
\hline
\end{tabular}

Introduction

Tobacco is an important commercial crop grown in India which occupies the third position in the world with an annual production of about 800 Million Kgs. Tobacco and tobacco products together earn approx Rs.20,000 Crores to the national exchequer by way of excise duty and approx. Rs.5000 Crores by way of foreign exchange every year. Flue Cured Virginia (FCV) tobacco is produced in the states of Andhra Pradesh and Karnataka. Belgium is the largest market for Indian FCV tobacco, followed by Russia and Germany. India exports
An on-farm demonstration was conducted for three years (2015, 2016 and 2017) during kharif and rabi season at farmers' field to assess suitable alternate crop and its economics during kharif and rabi season in southern black soils (SBS) of Prakasam district. Sole crop of FCV tobacco was compared with redgran, maize, jowar, chickpea, blackgram and safflower. Chickepea crop performed better in terms of net returns Rs.61750 ha ${ }^{-1}$ and B:C (1:2.52) ratio followed by :blackgram with net returns of Rs.61750 $\mathrm{ha}^{-1}$ and $\mathrm{B}: \mathrm{C}$ ratio of $(1: 2.40)$ as they fetched higher price in the market. Among the crops tried, maize, jowar and redgram were the next best remunerative crops as they recorded higher net returns of Rs. $32958 \mathrm{ha}^{-1}$, Rs.29871 ha ${ }^{-1}$ and Rs.29533 ha ${ }^{-1}$ respectively. Chickpea and redgram crops were to be economically viable alternate to FCV tobacco.

unmanufactured tobacco primarily to Western Europe, South \& South-East Asia, East Europe and Africa accounting for about 86 percent of exports. India is now considered the world's most dependable source for quality tobacco because of its low range of pesticide residues and heavy metals. Andhra Pradesh occupied the first place in area and second place in production particularly in FCV tobacco. Besides to its economic potential and labour absorption, area under tobacco has been decreasing significantly due to diminishing of market prices, high cost of production, decline in tobacco demand and prices in international market. In addition to 
this the government policies particularly health policies at international level has been one of the main reasons for the decline of tobacco area in India. Hence, tobacco growers in Andhra Pradesh are facing several problems in recent years in respect of growing tobacco in more area and at times produced more than their permissible limit, increased cost of production, most of tenant farmers depending on private finance at higher rate of interest, diverting some of the credit loan for social expenditure like education and health that has become very expensive now a days, on the other hand low market price due to less export orders resulting in huge losses.

FCV tobacco is mainly grown in four distinctive soil zones in A.P VIZ., Northern light soil (NLS), Southern light soils (SLS), Northern black soils (NBS) and Southern black soils (SBS) covering five districts. In Prakasam district it is being cultivated in both light (58.28\%-SLS) and black (41.72\%-SBS) soils and the crop was covered in 78,457 ha during 2014-15 out of 1,39,159 ha in Andhra Pradesh which accounts for 56.37 percent. But poor quality, low productivity and poor remunerative prices lead to farming of tobacco crop as non-profitable in addition to abiotic and biotic stresses. Government of India is gradually reducing the area under tobacco cultivation as per the World Health Organization Framework Convention on Tobacco Control. WHO aimed at reducing tobacco supply due to growing concerns about the health hazards of tobacco which in turn resulted in decreasing international demand for tobacco year to year, in view of the above the ITC who is the pioneer in tobacco business is forcing to reduce the area under tobacco cultivation in India even farmers have developed skills in tobacco cultivation and curing the tobacco with locally available barons, Because of reducing the tobacco cultivation barons are kept ideal and that leads to loss of income from tobacco crop and also wastage of money which was invested on the construction of curing structures (Barons). Traditional tobacco growers are slowly switching over to alternative remunerative crops to tobacco. In view of the above facts, the present investigation on identification of suitable alternate rainfed rabi crop in place of tobacco is highly essential to bring back tobacco growing farmers to viable state. It is necessary for the tobacco growers and the researchers to look for alternative crops and cropping systems, which are equally remunerative. Globally several investigations are carried to find alternative crops for tobacco. Existing studies indicate that farmers find it difficult to shift from tobacco to alternative crops because the cultivation of tobacco is considered profitable in monetary terms (Mahadevaswamy et al., (2006) and Kumar et al., 2010). Keeping this in view, onfarm demonstration was conducted to identifying the suitable alternative crops for tobacco with special reference to the southern black soils of Prakasam district of Andhra Pradesh.

\section{Materials and Methods}

District Agricultural Advisory and Transfer of Technology centre(DAATTC), Darsi, Prakasam district, Andhra Pradesh state conducted on-farm demonstration on alternate crops to tobacco at farmers' field to assess suitable alternate crop and its economics during kharif and rabi season of the year 2015-16, 2016-17 and 2017-18 in different tobacco cultivated villages viz., Obannapalem, Pothavaram, Ch.Uppalapadu, Chandaluru, Ammanabrolu, Alakurapadu of Prakasam district with redgram, blackgram, maize, jowar, chickpea and safflower, respectively. In one plot of the demonstration farmer's practices (Tobacco) were applied which was considered as control plot. All the selected crops were sown during rabi season except 
redgram, where redgram was sown during kharif season. A total six farmers were selected for conducting an on-farm demonstration with an area of 0.4 ha each. The soil of the demonstration field was clay loam in texture, slightly alkaline in reaction ( $\mathrm{pH}$ 8.2). One day training was given to the participating farmers of the respective villages to discuss with them the improved technologies from sowing to harvesting and other steps like site, farmer's selection and lay out of the demonstration before the sowing. Farmer-scientist interaction was organized at demonstration plots to disseminate the technology. All crops were line sown manually by adopting the recommended spacing for the above individual crops respectively. Recommended dose of FYM

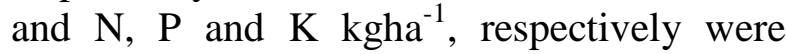
applied. $\mathrm{N}$ was applied in two splits. Entire FYM, $\mathrm{P}$ and $1 / 2$ of $\mathrm{N}$ applied as basal at the time of field preparation. $\mathrm{N}$ applied in the form of urea, $\mathrm{P}$ applied through single super phosphate respectively. Pre-emergence application of Pendimethalin @ 3.75 lit/ha at 3 DAS was sprayed as per the recommended spray volume of $500 \mathrm{Lha}^{-1}$. The data on yield attributes, yield and economics of crop were compared with the Tobacco. The economics was worked out based on the total cost of cultivation of each crop in the coastal districts of Andhra Pradesh and average price of the quintal seed of each crop was taken for estimation of $\mathrm{B}$ : $\mathrm{C}$ ratio. Cost of cultivation each crop is includes sowing to harvesting.

\section{Results and Discussion}

\section{Yield}

Tobacco yield varied from 1950 to 2125 $\mathrm{kg} / \mathrm{ha}$ averaging $2000 \mathrm{~kg} / \mathrm{ha}$ (Table 1). Maize and jowar performed with an average of 8292 and $5542 \mathrm{~kg} / \mathrm{ha}$ respectively, while chickpea and redgram achieved average yields of 2200 and $1317 \mathrm{~kg} / \mathrm{ha}$ respectively, where as safflower and blackgram showed average yields of 1342 and $1783 \mathrm{~kg} \mathrm{ha}^{-1}$ respectively. It could be seen from the data that in comparison to tobacco, sole crops of redgram and safflower did not match for its equivalent yield. Chickpea, maize, jowar and blackgram with equivalent value of 3206, 9215, 6205 and $2808 \mathrm{~kg} \mathrm{ha}^{-1}$, respectively were higher to tobacco. Maize, jowar, bengalgram and blackgram were found to be an alternative to tobacco in terms of average tobacco equivalent yield 9215, 6205, 3206 and 2808 $\mathrm{kg} \mathrm{ha}^{-1}$ respectively. While evaluating tobacco alternatives under European Union (EU), alternative scenarios and farm plans along with local soil conditions and rainfall is considered for getting higher income, alternative scenarios and farm plans along with local soil conditions and rainfall were considered for getting higher income, labour employment and environmental impacts (Basil et al., 2009). For EU, depending on the difficulties and diversifications, straw berries, melons, asperagus and chestnuts have been suggested as an alternative to tobacco (Beata et al., 2009). In Brazil, Tangania and Taiwan, more diversification of crop opportunity exists in view of engaging child labour, seasonal unavailability of skilled labours and wood as a fuel for curing (Helmut et al., 2009). Existing studies indicate that farmers find it difficult to shift from tobacco to alternative crops because cultivation of tobacco is considered as profitable in monetary terms (Hiremath, 2000 and Anon., 2007).

\section{Economics}

In this section, an attempt was made to present the costs and returns of tobacco, bengalgram, redgram, maize, jowar, safflower and blackgram in Table $2 \& 3$. As the livelihood security of the farmers directly depends on this aspect, it was subjected to comparison. 
Table.1 Yield and tobacco equivalent yield (yield kgha ${ }^{-1}$ ) of different alternate crops during kharif and rabi

\begin{tabular}{|l|c|c|c|c|c|c|c|c|}
\hline \multirow{2}{*}{$\begin{array}{l}\text { Alternate } \\
\text { crops }\end{array}$} & \multicolumn{4}{|c|}{ Yield $\left(\mathrm{kg} \mathrm{ha}^{-\mathbf{1}}\right)$} & \multicolumn{3}{c|}{ Tobacco equivalent yield (yield kgha-1 } \\
\cline { 2 - 10 } & $\mathbf{2 0 1 5 - 1 6}$ & $\mathbf{2 0 1 6 - 1 7}$ & $\mathbf{2 0 1 7 - 1 8}$ & Mean & $\mathbf{2 0 1 5 - 1 6}$ & $\mathbf{2 0 1 6 - 1 7}$ & $\mathbf{2 0 1 7 - 1 8}$ & Mean \\
\hline Redgram & 1125 & 1375 & 1450 & 1317 & 1676 & 1925 & 2061 & 1887 \\
\hline Chickpea & 2125 & 2175 & 2300 & 2200 & 3101 & 3294 & 3225 & 3206 \\
\hline Maize & 7750 & 8625 & 8500 & 8292 & 8659 & 9529 & 9458 & 9215 \\
\hline Jowar & 5500 & 5375 & 5750 & 5542 & 6202 & 6015 & 6398 & 6205 \\
\hline Safflower & 1375 & 1200 & 1450 & 1342 & 1880 & 1634 & 1976 & 1830 \\
\hline Blackgram & 1875 & 1650 & 1825 & 1783 & 3023 & 2593 & 2809 & 2808 \\
\hline Tobacco & 2125 & 2000 & 1950 & 2000 & 2125 & 2000 & 1875 & 2000 \\
\hline
\end{tabular}

Table.2 Economics of different alternate crop during kharif and rabi

\begin{tabular}{|l|c|c|c|c|c|c|c|c|}
\hline \multirow{2}{*}{$\begin{array}{l}\text { Alternate } \\
\text { crops }\end{array}$} & \multicolumn{4}{|c|}{ Cost of cultivation $\left(\right.$ Rs. ha $\left.^{-\mathbf{1}}\right)$} & \multicolumn{4}{c|}{ Gross returns (Rs. ha $\left.\mathbf{- 1}^{-1}\right)$} \\
\cline { 2 - 10 } & $\mathbf{2 0 1 5 - 1 6}$ & $\mathbf{2 0 1 6 - 1 7}$ & $\mathbf{2 0 1 7 - 1 8}$ & Mean & $\mathbf{2 0 1 5 - 1 6}$ & $\mathbf{2 0 1 6 - 1 7}$ & $\mathbf{2 0 1 7 - 1 8}$ & Mean \\
\hline Redgram & 28500 & 29500 & 27500 & 28500 & 54000 & 57750 & 62350 & 58033 \\
\hline Chickpea & 38750 & 41375 & 42000 & 40708 & 95625 & 117450 & 94300 & 102458 \\
\hline Maize & 57500 & 63750 & 61625 & 60958 & 89125 & 94875 & 97750 & 93917 \\
\hline Jowar & 36450 & 38500 & 37500 & 37483 & 68750 & 67187.5 & 66125 & 67354 \\
\hline Safflower & 23420 & 23500 & 25520 & 24147 & 49500 & 45600 & 53650 & 49583 \\
\hline Blackgram & 43750 & 41250 & 44500 & 43167 & 112500 & 99000 & 100375 & 103958 \\
\hline Tobacco & 171250 & 178000 & 171125 & 173458 & 201875 & 210000 & 198900 & 203592 \\
\hline
\end{tabular}

Table.3 Economics of different alternate crop during kharif and rabi

\begin{tabular}{|l|c|c|c|c|c|c|c|c|}
\hline \multirow{2}{*}{$\begin{array}{l}\text { Alternate } \\
\text { crops }\end{array}$} & \multicolumn{4}{|c|}{ Net returns $\left(\right.$ Rs. ha $\left.^{-1}\right)$} & \multicolumn{4}{c|}{ C:B ratio } \\
\hline Redgram & $\mathbf{2 0 1 5 - 1 6}$ & $\mathbf{2 0 1 6 - 1 7}$ & $\mathbf{2 0 1 7 - 1 8}$ & Mean & $\mathbf{2 0 1 5 - 1 6}$ & $\mathbf{2 0 1 6 - 1 7}$ & $\mathbf{2 0 1 7 - 1 8}$ & Mean \\
\hline Chickpea & 25500 & 28250 & 34850 & 29533 & $1: 1.89$ & $1: 1.96$ & $1: 2.27$ & $1: 2.04$ \\
\hline Maize & 31625 & 31125 & 36125 & 32958 & $1: 1.55$ & $1: 1.49$ & $1: 1.59$ & $1: 1.54$ \\
\hline Jowar & 32300 & 28687.5 & 28625 & 29871 & $1: 1.89$ & $1: 1.75$ & $1: 1.76$ & $1: 1.80$ \\
\hline Safflower & 26080 & 22100 & 28130 & 25437 & $1: 2.11$ & $1: 1.94$ & $1: 2.10$ & $1: 2.01$ \\
\hline Blackgram & 68750 & 57750 & 55875 & 60792 & $1: 2.57$ & $1: 2.40$ & $1: 2.26$ & $1: 2.41$ \\
\hline Tobacco & 30625 & 32000 & 27775 & 30133 & $1: 1.18$ & $1: 1.18$ & $1: 1.16$ & $1: 1.17$ \\
\hline
\end{tabular}


The total cost of cultivation for tobacco was highest (Rs. 1, 73,458) when compared with maize (Rs.60958), blackgram (Rs.43167), bengalgram (Rs. 40708), jowar (Rs.37483), redgram (Rs.28500) and safflower (Rs.24147) per ha ${ }^{-1}$.

When gross returns per hectare were compared FCV tobacco earns Rs.2,03,592, which was higher compared to bengalgram (Rs.1,02,458), blackgram (Rs.1,03,958) and maize (Rs.93,917), jowar (Rs.67,354), redgram (Rs.58,033) and safflower (Rs.49,583). It was noticed that, gross returns from FCV tobacco was nearly two times higher than from bengalgram, blackgram, maize and three times higher than jowar but in safflower, redgram it was four times more. Net returns per hectare were compared FCV tobacco earns Rs.30133, which was lower when compared to bengalgram (Rs.61750), blackgram (Rs.60792) and maize (Rs.32958), but which was lower when compared to compared to jowar (Rs.29871), redgram (Rs.29513) and safflower (Rs.25437).

In terms of return per rupee expenditure was highest in chickpea (2.52) followed by blackgram (2.40), redgram (2.04) and safflower (2.01), which were observed as more or less similar, interestingly. Ratnam, et al., (2014) reported that bengalgram was found to be alternative to tobacco in terms of tobacco equivalent yield in $\mathrm{kg} \mathrm{ha}^{-1}$ but in terms of monitory returns ( $\mathrm{C}: \mathrm{B}$ ratio) cowpea followed by cluster bean was found to be an alternative to tobacco. However, it was well noticed that chickpea and blackgram were profitable crop with highest net returns of Rs.61, 750 and 60,792 respectively, when net returns was considered as a criterion to judge best alternative crops, So chickpea and balckgram in un irrigated conditions and maize in irrigated conditions were observed as next best alternative crops to FCV tobacco for Prakasam district of Andhra Pradesh
It can be concluded that the chickpea, Blackgram and redgram can be economically viable alternatives to FCV tobacco crop for the farmers of Prakasam district of Andhra Pradesh.

\section{References}

Anonymous, 2007, Status Report for Research Programmes on Alternative Crops to Tobacco, Central Tobacco Research Institute, Rajahmundry, Andhra Pradesh.

Basil, M., Thomas, B., Jason, P. S. and Parthene, C., 2009, Evaluation of tobacco cultivation alternatives under EU common agricultural policy. J. Policy Modeling, 31(2): 225-238.

Beata, B., Anitha, M.K., Tibor, O. and Janos Borsos, D.S.C., 2009, Difficulties of diversification and alternative crops to tobaccoin European Union. Paper presented in Int. Cong. 4th Aspects Visions Appl. Econ. Infmn., 1121-1127.

Helmut, J.G., Kang-tsung, C., Virginia, E. and Jumanna, M.A., 2009, Tobacco growers at the cross roads: Towards a comparison of diversification and eco system impacts. Land Use Policy J., 26(4):1066-1079.

Hiremath, G.K., 2000, Economics od BIDI V/S competing crops. Paper presented In: Tobacco Nation. Sem. Nov, 29-30, 2000, Univ. Agric. Sci., Dharwad (India).

Krishna Teja I., Rajeswari S., Bhavani Devi I. and Ravindra Reddy B. (2016) International Journal of Research in Applied, Natural and Social Sciences, 4 (10), 115-122.

Kumar M.D., Naik D.C., Sridhara S., Vageesh T.S., Girijesh G.K and Rangaiah S. (2010) Karnataka Journal of Agricultural Sciences, 23(5), 689-692.

Mahadewaswamy M., Giridhar K. and Harishukumar (2006a) Tobacco Research, 32(2), 73-75.

Ratnam M., Sunil M. AND Suneel Kumar 
G.V. (2018) Identification of alternative crop for tobacco for Prakasam district of
Andhra Pradesh. International Journal of Agriculture Sciences 10 (22):7514-7515.

\section{How to cite this article:}

Ramesh, G., Ch. Varaprasada Rao and Prasada Rao, G. M. V. 2020. Evaluation of Viable Alternative Crops for FCV Tobacco in Southern Black Soils of Prakasam District of Andhara Pradesh, India. Int.J.Curr.Microbiol.App.Sci. 9(08): 3949-3954.

doi: https://doi.org/10.20546/ijcmas.2020.908.454 